Journal of Teacher Education for Sustainability, vol. 23, no. 1, pp. 5-21, 2021

\title{
A Holistic Approach to Education for Sustainability: Ecofeminism as a Tool to Enhance Sustainability Attitudes in Pre-service Teachers
}

\author{
Yolanda Echegoyen-Sanz and Antonio Martín-Ezpeleta \\ University of Valencia, Valencia, Spain
}

\begin{abstract}
To achieve an effective Education for Sustainable Development (ESD), teachers should possess appropriate sustainability attitudes to transmit those values to their future students. In this article, a holistic educational intervention around the ecofeminist movement is described and its impact on the sustainability attitudes of 188 pre-service teachers is assessed. The quantitative results with a validated questionnaire reveal an initial high level of sustainability awareness and a statistically significant increase in the environmental dimension after the educational intervention. In addition, the qualitative analysis of the stories and activities for children prepared by the students in a process of didactic transposition confirms their ability to effectively integrate different competencies around a topic. Due to their status as future educators in the early stages of the system, preservice teachers are relevant to disseminate a holistic view of ESD and we can conclude that ecofeminism is a thematic node that integrates key concept and attitudinal content to achieve that goal.
\end{abstract}

Key words: attitudes, sustainability, environmental humanities, pre-service teachers, ecofeminism

\section{Introduction}

The well-known Sustainable Development Goals were adopted by the United Nations in September 2015 after the successes of the Millennium Development Goals and are a universal call to action to end poverty, protect the planet and ensure that all people enjoy peace and prosperity (UNDP, 2015). There are 17 interconnected goals among which we can find one related to "gender equality" (number 5) and several others related to the environmental part of sustainability, i.e., "clean water and sanitation" (number 6), "affordable and clean energy" (number 7), "climate action" (number 13), etc. To be able to achieve these goals, it is imperative to train responsible citizens to be aware of the existing problems and the interconnections among them, and this can only be managed through education at all levels. To produce socially responsible citizen adults, schools have traditionally been expected to take responsibility for children's moral 
learning (Grieshaber \& McArdle, 2014), so early childhood and elementary educators play a decisive role.

As a consequence, teacher education is a key factor to achieve an effective Education for Sustainable Development (ESD) in the citizenship. There are different approaches to embedding sustainability in teacher education, either across curriculum areas, a compulsory subject or part of one, or an elective subject (Evans et al., 2017). It is also clear that this education should be innovative, multidisciplinary and also feminist. Projectoriented learning has been stated as an excellent methodology for developing competencies in sustainability (Albareda-Tiana et al., 2018). In this context, ecofeminism as a transdisciplinary approach related to problem/phenomenon based learning (Blumenfeld et al., 1991) that permits to address sustainability from a holistic point of view has a great potential to be included in teacher training programs to address at the same time environmental sustainability and women empowerment as part of social sustainability.

The adequate preparation of pre-service teachers in environmental education and gender inequalities is a pre-requisite for their future ability to design and implement an effective gender and environmental education and transmit a holistic view of sustainability issues. To change the educational paradigm from mechanistic to holistic (Nava, 2001), teachers have to be aware of the intrinsic connections between science, ecology, society and spirituality. As Gough and Whitehouse (2019, p. 332) state, "it is time for gender to be much higher on the agenda of environmental education". For this reason, ecofeminism (also called ecological feminism) as part of the environmental humanities (Heise et al., 2017) and being a philosophy that combines both perspectives, can be a suitable tool to raise environmental and gender awareness at the same time in preservice teachers. This interdisciplinary movement, with disciplines such as anthropology, sociology, philosophy or ecology and whose origins can be traced back to the 70s of the last century, offers very interesting educational possibilities (Echegoyen-Sanz, 2019).

The aim of this research is to assess the effectiveness of an educational intervention based on ecofeminism on the sustainability awareness of pre-service teachers in a pretestposttest experimental design. Here we describe the process and outcome of incorporating some ecofeminism-related activities to raise environmental and gender awareness in pre-service teachers. With the aim of developing their creativity and their capacity of integrating different subjects around the topic, one of those activities was a didactic transposition exercise of writing short stories and related activities for children. Both a validated questionnaire and a qualitative analysis of the products were used to answer the following questions:

What are the sustainability attitudes of pre-service teachers?

To what extent do pre-service teachers demonstrate changes in their sustainability attitudes over the course of the intervention?

Is there any difference between genders?

What are the previous ideas of the students about the relationship between feminism and ecology?

How do they address the environmental and gender issues in the creative storytelling workshop? 


\section{Theoretical Background}

\section{Education for Sustainability and Sustainability Attitudes}

A fundamental challenge that society faces today is sustainable development, with a debate centered on how to develop our world socially and economically while achieving environmental sustainability. The role of education in sustainable development has been highlighted by different policies at the international level (UNESCO, 2006; 2014) and actions like the UN Decade of Education for Sustainable Development between 2005 and 2014 or the following Global Action Programme (GAP) from 2015 onwards.

The complexity of the issues and conflicts of interest involved in sustainability makes it necessary to focus ESD on reflecting on issues instead of teaching a right answer to a response (Lijmbach et al., 2002), providing a holistic view of sustainability issues and the use of learner-centered teaching strategies. This particularity of ESD entails a challenge for teachers and schools to implement effective programs for sustainability education. Shephard (2008) also indicated that the affective domain (values, attitudes and behaviors) could be used to benefit ESD while most teaching in higher education focused rather on cognitive skills.

The importance of the affective domain is also reflected in the growing body of quantitative research measuring competences, attitudes and beliefs in environmental education and ESD. The issues involved in the construction of assessment tools have been studied by different authors (Powell et al., 2011; Olsson, Gericke, \& Chang, 2015; Schneller, Johnson, \& Bogner, 2015). Michelle Biasutti and Sara Frate highlight that "a scale measuring environmental attitudes does not necessarily mean that it measures attitudes toward the environmental dimension of sustainability" (Biasutti \& Frate, 2017, p. 218). They also indicate that all the existing questionnaires focus on the three pillars of sustainability (environment, economy and society), but lack a focus on education, as we have seen a crucial component of ESD. In this study, we use the "Attitudes toward Sustainable Development Scale", a quantitative scale developed by those authors for university students including the dimension "education", a key aspect of sustainability and very interesting for research with pre-service teachers.

\section{The Educational Potential of Ecofeminism in ESD}

The term "ecofeminism" first appeared in 1974, in the book Le Feminisme ou la Mort (Feminism or Death), by Françoise D’Eaubounne, which establishes a relationship between the devastation of nature, overpopulation and male domination. Ecofeminism has always been an activist and academic movement at the same time and consequently ecofeminists have been involved in such important problems as, for example, toxic waste, animal rights, deforestation or agricultural development. At the beginning of the $21^{\text {st }}$ century, there was a regression of the so-called classical ecofeminism. However, in recent years it has been experiencing resurgence in the hand of new proposals that are more inclusive than exclusive.

In this sense, Yayo Herrero (2016) proposes to distinguish two main ecofeminist currents. The first one is classical or essentialist ecofeminism that understands that women are closer to nature and have a tendency to preserve it because they are able to give birth, breastfeed and menstruate. The second one is constructivist ecofeminism arguing that the traditional sexual division of labor and the distribution of power and 
property in patriarchal societies make the relationship between women and nature more intimate and, therefore, their special ecological awareness is a social construction. Thus, it is women in many cultures who are responsible for protecting nature, not because of genetic predisposition or taste, but because they have to deal with energy and material supply, guaranteeing subsistence conditions.

It is known that to change social, spiritual, cultural and environmental crises around the world, both non-formal and formal education are critical tools (Clover, 1995). One way to achieve that change is the integration of ecofeminism in the education systems. In fact, as experts in ecofeminism have been suggesting in their numerous studies, ecofeminism has a fundamental educational dimension. These educational possibilities of ecofeminism are evident in different works. Li (2007) or Gough and Whitehouse (2019) understand that ecofeminism can be part of a pedagogical project that emphasizes ethical activism in oppressive contexts, examines established social norms or explores the possibilities of establishing new ethical norms in the global community. Harvester and Blenkinshop (2010) go a step further and propose to build ecofeminist schools, leaving behind the concept of traditional school to use a new paradigm, a 'learning village' (p. 128) to implement ecofeminist pedagogy. There are also many successful examples of educational proposals based on feminist pedagogy (Wen-Hui, 2013).

Focusing on Environmental Education and ESD, Russell and Bell (1996) conclude that for it to be truly transformative, students have to experience both the desire and the possibility of being actively involved. All this will have repercussions in an authentic ecofeminist pedagogy. Spencer and Nichols (2010) point out that we must take a special care to stop presenting the environment as a problem. The historical reasons should be explained within which one cannot ignore the ecofeminist perspective, which Zell (1998) previously denounced that was systematically eclipsed. Gough (1999) also stresses the gaps and silences present in policies, pedagogy and research in environmental education from a feminist perspective. The importance of gender in structuring disciplines and teaching strategies has been well established (Herman \& Kirkup, 2017), and it is necessary to achieve holistic education. In fact, some authors as Henderson (1997) demonstrate how a philosophy such as ecofeminism might influence the actions of individuals toward one another and toward the environment, addressing both social and environmental aspects of sustainability. It is also postulated that environmental education can inspire women from all race and class backgrounds to engage in effective ecological and political action by incorporating findings about gender differences in motivation, attitudes, and behaviors (Sakellari \& Skanavis, 2013). Moving towards culturally-responsive teaching and learning practices in ESD is a request (Blanchet-Cohen \& Reilly, 2013). However, despite the fact that ecofeminism seems an excellent starting point to achieve a holistic view of sustainability issues interlinking gender and environmental education, there are not many concrete teaching units (Echegoyen-Sanz, 2019; Echegoyen-Sanz \& MartínEzpeleta, 2021) or specific materials to translate this philosophy to the classrooms. 


\section{Methodology}

\section{Participants}

The participants were undergraduate students at their sophomore year of Primary Education or Early Childhood Education at a large public Spanish university. Data reported here pertain to four groups of students who were enrolled in the subject "Natural Sciences for Teachers" during 2017-2018 and 2018-2019 academic years. Of the 188 pre-service teachers who completed the course, the mean age was 19.98 (median =19), with a standard deviation of $1.69 ; 148(78.7 \%)$ were female and 40 (21.3\%) - male.

\section{Educational Intervention}

The innovative educational intervention, structured in three phases, focused on the competencies and strategies that the students should learn. First, an initial assessment of the knowledge and beliefs of the students about ecofeminism was carried out by the completion of a short questionnaire with the following open and closed questions:

(1) Have you heard the term "ecofeminism" before?

(2) What do you think it refers to?

(3) Do you think women are closer to nature than men? Justify your answer.

(4) Do you think the same can be applied to different cultures?

After analyzing the results, we can conclude that ecofeminism is a philosophy mostly unknown to the students. Only $16.5 \%$ declare that they had heard the term "ecofeminism", but most of them were not capable of giving an exact definition, they only said that it combined ecology and feminism or women. Just three students ( 2 male, 1 female) gave a most detailed definition:

"the search and active defense of achieving a political, social and economic equality for the two genders, in particular with an ecological approach, that is, the same equality for all living beings on the planet and sustainable development” (S.V.);

"ecologist and feminist movement that establishes an important relationship between the sustainable exploitation of natural resources and the struggle against machismo and heteropatriarchy, in order to reach a fairer society with guarantees for the future" (J.R.);

"branch of feminism that integrates the theme of nature in his speech, breaking the comparison between women and nature" (N.E.).

$71 \%$ of the students considered that men and women were equally close to nature, with no significant differences between male and female students. Of those that considered women closer to nature approximately $48 \%$ had an essentialist ecofeminism view with reasons like they were able to give birth or create life, feed their children with their own bodies, have maternal instinct, the maternity, menstrual cycles, etc. The rest considered social or anthropological reasons like traditional female roles were closer to natural sciences than those of male; women were more aware and involved in solving environmental problems; their role as caregivers to other human beings and, in extension, to plants and animals, etc. 
During the semester the students read the short novel Yabari by Lola Robles (2017). It is a science fiction dystopia in which mankind has to migrate to other planets to obtain resources. In the novel a parallelism between the way men treated women and the planet Yabarí to exploit its resources is evident. The human nature relationship portrayed in the novel is clearly related to the current trend in global development known as Anthropocene (Salite, 2015; Salite et al., 2019). There is also a reflection on the different relationship of Yabari's inhabitants with nature as opposed to what happens on the Earth; they are individual organisms entwined within a matrix larger than their individual selves. After reading the book students realized that all life on the Earth is interconnected. Human beings, as animals and thus part of nature, are deeply connected to other beings and the environment. As part of holistic education, the idea of a connection between oneself, the whole society and nature, as well as a necessary balance between them was emphasized in a group discussion of the work.

In the first session of the educational intervention, in order to introduce ecofeminism, the students read a short text about Amrita Devi's story. She was a woman from Rajasthan India who sacrificed her life along with her three daughters in 1730 to save green trees being felled by the Maharaja in order to save the forest from the soldiers and started the Chipko (save trees) movement. Then, in three to four people randomly selected groups, a small web quest about the history of the Chipko movement, their achievements and similar events took place. In the second session, the teacher gave a lecture about the theory of ecofeminism and some of the most known ecofeminist movements highlighting both the social and environmental implications. In the third session, a debate took place during which the conceptions and beliefs of the students around science, ecology, sustainability, feminism and their convergence arose. This learning environment tried to accommodate at the same time individual and group learning, while facilitating both analytical and inductive thinking, as Gang (1993) considered crucial for holistic education.

Authors like Badjanova et al. (2014) indicate that teachers face difficulties in implementing a sustainability perspective because they usually have to create their own materials grounded in the idea of sustainable education and only those really aware of sustainability issues are able to do so. Also, if we want future teachers to be able to apply successfully a holistic approach in their professional future, they should develop their creativity and figurative and constructive thinking (Badjanova, 2013). In this sense, the last activity in the educational proposal was a didactic transposition (Chevallard \& Bosch, 2014) where pre-service teachers had to translate their knowledge and gender balanced environmental education to their future students. It took place in the form of a small creative literary workshop with the writing of stories for children. From a holistic view, storytelling is a natural way to teach children about ethical, environmental or moral obligations with the possibility of leading to broader discussions of sustainability (Alghamdi et al., 2017). This holistic approach as described by Lemkow (1990) bridging the gap that dichotomizes Sciences and Arts, also had a very good acceptance and results in previous studies with pre-service teachers (Echegoyen-Sanz \& Martín-Ezpeleta, 2018; Martín-Ezpeleta \& Echegoyen-Sanz, 2020). For this purpose, they prepared an "ecofeminist" story for children, this is, a story in which the main character had to be a female with an active approach to an environmental issue of their choosing, coupled with different activities around the text to work sustainability and gender equality issues with the children in the classroom. The first one had to be related to reading compre- 
hension, the second one to visual arts and the last one to environmental protection, trying to generate a multidisciplinary and holistic approach to their texts.

In order to generate a gender equal and fair educational environment, teachers who hold unbiased gender beliefs and who are aware of gender issues are needed (Erden, 2009). On the other hand, the inclusion of sustainability as part of the core focus of teacher education policies and practices is crucial (Evans et al., 2017). The holistic educational intervention here presented is an alternative to achieve both goals at the same time, as we will demonstrate below.

\section{Data Collection Instrument and Data Processing}

The change in sustainability attitudes was studied by using the "Attitudes toward Sustainable Development Scale” (Biasutti \& Frate, 2017). This is a quantitative 20-item scale with four dimensions: environment (ENV), economy (ECON), society (SOC) and education (EDU). The response format for the items was a 5-point Likert scale. As the authors stated, this questionnaire could be useful for understanding the ways in which students think about sustainability issues and could be used to investigate the relationship between sustainability attitudes and other variables. Internal reliability, which was found using Cronbach's alpha, varied between .660 and .854 .

Pretest data collection took place at the beginning of the semester (January 2018 and January 2019) and posttest was completed at the end of the semester (May 2018 and May 2019). Both times students filled the questionnaires online in the computer classroom.

Descriptive statistical analysis of the pretest and posttest results was done using SPSS software version 26. Particularly mean and standard deviation was calculated for each of the factors in the questionnaire. To check the normality of the distributions Kolmogorov-Smirnov test for one sample was used. For normal distributions, Student's t-test for independent samples (gender analysis) or related samples (pretest-posttest comparative) was used, after Levene test to assess the equality of variances. For nonnormal distributions Kruskal-Wallis test was used for independent samples and Wilcoxon signed-rank test was used for related samples. In all cases the significance level was 0.05 .

\section{Analysis of the Written Stories and Activities Prepared by the Students}

Qualitative analysis software Atlas.ti v8 was used to support the analysis process. 188 primary documents (the stories for children written by the students with the associated activities) composed the hermeneutic unit of the analysis project. An iterative analysis consisting of close reading, organizing, interpretation, and summarizing was followed. First, we read the stories thoroughly several times to obtain an overall familiarity and understanding. Then, based on the active, in-depth familiarization with the data, initial codes were created attending to the environmental issues and the literary characteristics of the narratives (characters, setting, plot...), as well as the type of proposed activities. During the second stage, the codification of cites related to the social, emotional and affective aspects took place. Codes were exclusive and with no overlap between them. The codification was made by two coders and the inter- and intra-coder agreement was higher than $80 \%$. 


\section{Results and Discussion}

\section{Quantitative Analysis. Evolution of Sustainability Attitudes}

The results of the descriptive statistical analysis for the initial and final questionnaires are shown in Table 1. As can be seen, at the beginning of the semester the students already had high sustainability attitudes in all dimensions of the questionnaire, although somewhat lower in the environment dimension, being the only value below 4 . The highest value of all was the one related to education (4.60), a logical one taking into account that they are pre-service teachers and aware of the importance of education to address sustainability (among other) issues. According to AkÇa (2019), prospective teachers have stronger beliefs about ESD than those enrolled in the Pedagogical Formation Certificate Program. This trend of the influence of bachelor on sustainability attitudes has also been stated by Biasutti and Frate (2017). In their study, agriculture students performed better on the environment factor than psychology students, thus demonstrating stronger attitudes toward environmental care, whereas psychology students performed better on the society factor, thus demonstrating more sensibility toward social issues.

\section{Table 1}

Descriptive Statistics for the Initial and Final Questionnaires

\begin{tabular}{lcccccccc}
\hline \multirow{2}{*}{ Dimensions } & \multicolumn{3}{c}{ Initial questionnaire } & \multicolumn{3}{c}{ Final questionnaire } \\
\cline { 2 - 9 } & Min & Max & Mean & SD & Min & Max & Mean & SD \\
\hline Environment & 1.80 & 5.00 & 3.77 & 0.69 & 1.20 & 5.00 & 4.15 & 0.74 \\
Economy & 1.20 & 5.00 & 4.35 & 0.74 & 1.40 & 5.00 & 4.37 & 0.61 \\
Society & 1.00 & 5.00 & 4.55 & 0.82 & 1.00 & 5.00 & 4.60 & 0.61 \\
Education & 1.00 & 5.00 & 4.60 & 0.61 & 1.00 & 5.00 & 4.58 & 0.66 \\
\hline
\end{tabular}

The evolution on the mean values of the different dimensions can be observed in Figure 1. We can see that there is almost no difference between the initial and final values of the economy, society and education dimensions, but the value for the environment dimension has increased at the end of the semester (from 3.77 to 4.15).

\section{Figure 1}

\section{Mean Values of the Different Dimensions in the Initial and Final Questionnaires}

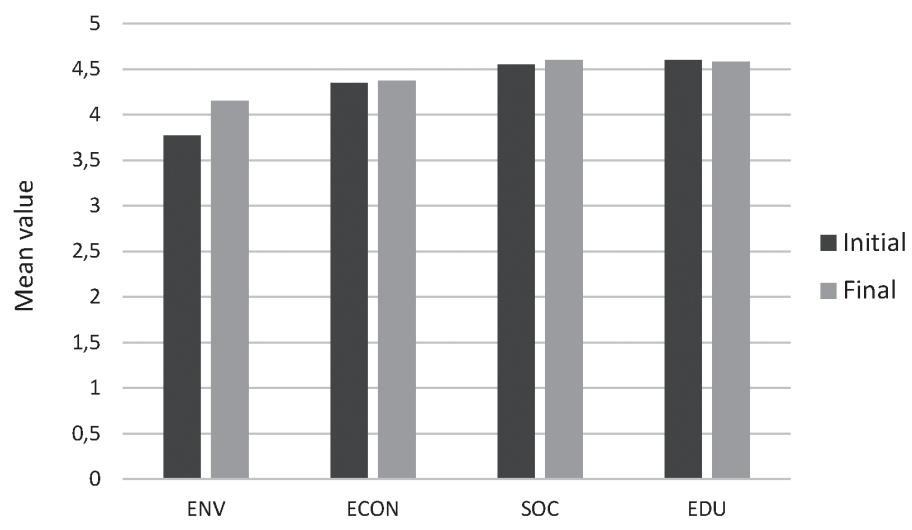


It is worth noting that our results in all dimensions (even at the beginning of the semester) were much higher than those obtained by Abu-Alruz et al. (2018) with undergraduate students at the Faculty of Education of a public university in Jordan $(\mathrm{ENV}=2.66, \mathrm{ECO}=3.15, \mathrm{SOC}=3.10, \mathrm{EDU}=3.17)$. This can be understood by the socioeconomic differences between the two countries; it has been demonstrated (Mónus, 2019) that even in the same country aspects of environmental awareness are strongly determined by the students' socioeconomic background. Berglund et al. (2020) also point out to the cultural context as a factor determining the sustainability consciousness.

To evaluate if the observed differences between the pretest and the posttest were statistically significant, a statistical analysis of the results obtained for the different dimensions was carried out. First, a Kolmogorov-Smirnov test was applied to every set of data and the appropriate statistical treatment according to the normality of the distribution was applied. The results are shown in Table 2. No significant differences were found for the economy, society or education dimensions, probably due to the very high consciousness of our students in these aspects at the beginning of the semester. However, there was a significant difference in the dimension environment, demonstrating that our approach to these issues was effective to raise the environmental awareness of the alumni.

Table 2

T-Test for Dependent Samples Between Pretest and Posttest

\begin{tabular}{lcccc}
\hline \multicolumn{1}{c}{ Dimension } & & Media & SD & $\sigma$ \\
\hline \multirow{2}{*}{ ENV } & Initial & 3.77 & 0.69 & $0.041^{* *}$ \\
& Final & 4.15 & 0.74 & \\
ECON* & Initial & 4.35 & 0.74 & 0.676 \\
& Final & 4.37 & 0.61 & \\
SOC* & Initial & 4.55 & 0.82 & 0.843 \\
& Final & 4.60 & 0.61 & \\
EDU* & Initial & 4.60 & 0.61 & 0.181 \\
& Final & 4.58 & 0.66 & \\
\hline
\end{tabular}

* Due to the non-normality of the distributions the Wilcoxon signed-rank test was used.

$* *$ There are significant differences with a significant level of 0.05 .

In most of the published studies related to environmental/sustainability attitudes, there are differences between genders, being women those with a higher environmental consciousness (Fremerey \& Bogner, 2015; Sutton \& Gyuris, 2015; Bergman, 2016; Martín Ezpeleta \& Echegoyen Sanz, 2020). On the other hand, there are also studies that did not find any significant difference between genders in these issues (Larson, Castleberry, \& Green, 2010; Levine \& Strube, 2012; Lieflander \& Bogner, 2014). These differences are generally explained according to gender roles and socialization (Bloodhart $\&$ Swim, 2020).

Our data according to gender is shown in Table 3. There seems to be, in general, higher consciousness of all dimensions of sustainability for female than male students. Values obtained by female students are higher both in the pretest and the posttest results. However, the statistical analysis shows no significant differences between genders except 
for the dimension society in the posttest, so we can conclude that in our case all students have a similar sustainability awareness.

Table 3

T-Test for Independent Samples Between Pretest and Posttest Results According to Gender

\begin{tabular}{|c|c|c|c|c|c|}
\hline & Dimension & & Media & SD & $\sigma$ \\
\hline \multirow[t]{8}{*}{ Initial questionnaire } & \multirow{2}{*}{ ENV } & Female & 3.80 & 0.65 & \multirow{2}{*}{0.576} \\
\hline & & Male & 3.64 & 0.84 & \\
\hline & \multirow{2}{*}{ ECON* } & Female & 4.39 & 0.62 & \multirow{2}{*}{0.823} \\
\hline & & Male & 4.20 & 1.09 & \\
\hline & \multirow{2}{*}{ SOC* } & Female & 4.61 & 0.69 & \multirow{2}{*}{0.461} \\
\hline & & Male & 4.34 & 1.19 & \\
\hline & \multirow{2}{*}{ EDU* } & Female & 4.62 & 0.68 & \multirow{2}{*}{0.331} \\
\hline & & Male & 4.54 & 1.25 & \\
\hline \multirow[t]{8}{*}{ Final questionnaire } & \multirow{2}{*}{ ENV } & Female & 4.18 & 0.63 & \multirow{2}{*}{0.527} \\
\hline & & Male & 4.00 & 1.08 & \\
\hline & \multirow{2}{*}{ ECON* } & Female & 4.42 & 0.42 & \multirow{2}{*}{0.329} \\
\hline & & Male & 4.22 & 1.07 & \\
\hline & \multirow{2}{*}{ SOC* } & Female & 4.65 & 0.31 & \multirow{2}{*}{$0.016 * *$} \\
\hline & & Male & 4.40 & 1.20 & \\
\hline & \multirow{2}{*}{ EDU* } & Female & 4.63 & 0.41 & \multirow{2}{*}{0.157} \\
\hline & & Male & 4.36 & 1.22 & \\
\hline
\end{tabular}

* Due to the non- normality of the distributions, the Kruskal-Wallis for independent samples test was used.

$* *$ There are significant differences with a significant level of 0.05 .

\section{Qualitative Analysis of the Written Stories and Proposed Activities}

The ecofeminist stories that our students wrote had mainly little girls as the main characters, although in some cases teenagers (5.3\%), grown women $(22.1 \%)$ or even animals (in three cases, a squirrel, a toucan and a turtle) were selected as the driving forces of the necessary change of attitude to save the planet. It is worth noting that when the main character was an adult woman in $20 \%$ of the cases, she was a school teacher (all of these stories were written by female students). A teacher figure helping the main character appeared in $22.3 \%$ of the stories, and a school in $28.7 \%$. This seems to hold the theory that the students projected themselves in the narratives; some of the written stories could be considered "autobiographic". 
Figure 2

\section{Absolute Frequency of the Environmental Problems Addressed in the Stories}

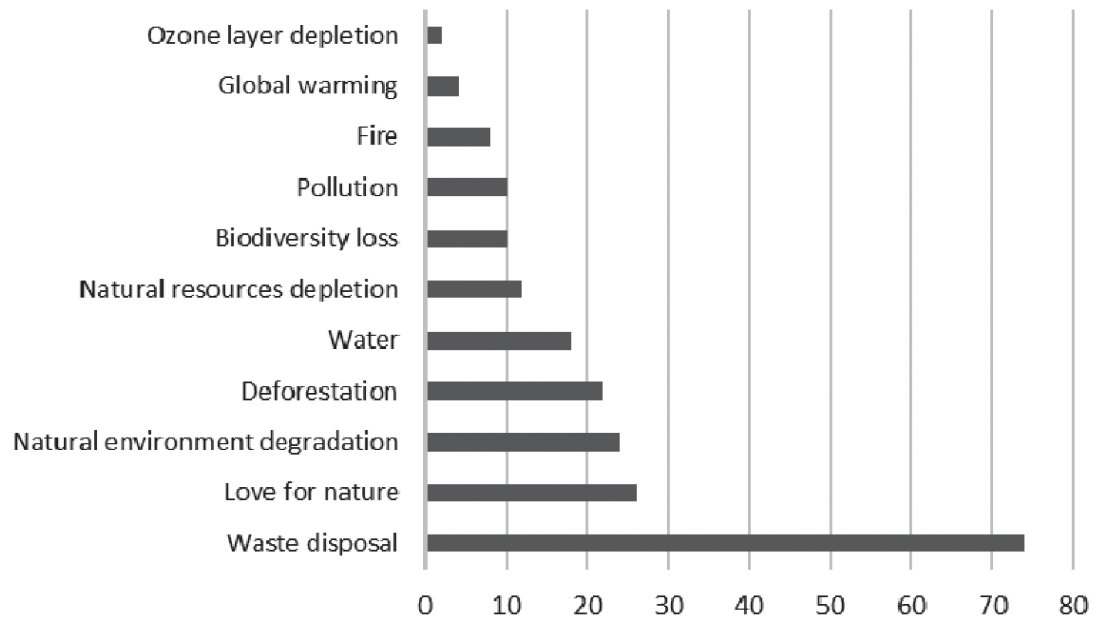

The selected environmental problems are shown in Figure 2. The most recurrent was waste disposal (35.2 \%). In these cases, almost a third of the stories included the solution of recycling or the three $\mathrm{R}$ rules (reduce, recycle and reuse), sometimes even with modifications of classic tales like "The little red riding hood" that was converted to "The recycling little green riding hood" who befriended the wolf and together collected litter from the forest. The following most selected topics were generic love for nature $(12.4 \%)$, natural environment degradation (11.4\%) and deforestation $(10.5 \%)$. Other topics were overexploitation of natural resources, quality and quantity of water, endangered species, global warming, ozone layer destruction, etc.

Most of the stories were day-to-day, quotidian stories that could happen to any child, so the audience could perfectly identify themselves with the little girls that were able to change things to save the planet. Sometimes the girl or woman had a flower name (Daisy, Lily...) to identify the main character with nature. In some cases, the stories took place in faraway lands, with dragons, princesses and castles, or there was magic in the world and the children were able to talk to plants and animals, or even transform into them to know their feelings about what mankind was doing to the environment. According to the co-occurrence table obtained with Atlas.ti v8, the most common short story would be a little girl attending school (coef. $=0.14)$, where a teacher helped her (coef. $=0.12$ ) to tackle the problem of litter or residues (coef. $=0.11$ ) and who expressed negative emotions about the problem $($ coef. $=0.23)$ in a realist tale $($ coef. $=0.24)$ situated at the present time (coef. $=0.27$ ).

The final task was to prepare three activities related to their text in three areas: reading comprehension, visual arts and environmental awareness. The need for an interdisciplinary approach to environmental education has been already pointed out due to the poor "state of environmental education and the need for improvement in ecological literacy” (Staples, 2005, p. 6).

In this case, the pre-service teachers' activities related to visual arts varied, including drawings of different parts of the story like "draw what the ideal forest would be like 
for you, and then paint it with the colors that you think are the best for a healthy forest" or "draw on one side the landscape that you imagine of the factory and on the other the landscape with the reconstructed environment"; prepare different animals with recycled materials; build a mural till the top of the classroom simulating the tree in the story; prepare different flowers with clay, etc.

As for the activities related to environmental awareness, they include from trips to different natural settings, to the planting of trees or different plants in the school or some more elaborated proposals like creating groups of children in every classrooms (that will change over the year) with an assigned duty: "water policemen" (they will have to make sure that there is no waste of water, i.e., taps closed when not in use, responsible use of water...); "trash bin policemen" (they will make sure that all the litter has been discarded to the correct container) and "clean space policemen" (they will check if all spaces in the school are clean, with no litter on the floor).

As Lawler (2008, p. 32) stated, stories provide "organizing devices through which we interpret and constitute the world" and those influence us generally in unconscious ways, in ways inaccessible to us in a straightforward manner (Storey, 2012). The importance of providing a gender-balanced view in different areas of education is crucial; in fact, gender equality has been in the international agenda for some time (Raftery \& Valiulis, 2016) and it is the prospective teacher who has the responsibility of working toward the objectives of equality in schools (Andersson et al., 2009). The future teachers also play an important role in changing the relationship between children and the planet; this is an issue that must be addressed since the disastrous human-induced state of the environment (along with neoliberalism or capitalist ideas) demonstrates the lack of connection between humans and the Earth (Iorio et al., 2017). Moreover, it is well established that existing paradigms and frameworks can be resisted, mitigated, or confronted by telling stories differently (Nagar, 2013). Thus, if we provide children with stories in which women are empowered and taking environmental action in their own hands, we will be able to influence both their environmental attitudes and their social construct of the world, including their gendered understandings of different matters.

\section{Conclusions}

To the sample studied, the described educational intervention with a holistic approach to ESD around the ecofeminism movement has been shown to have an impact on the environmental attitudes of pre-service teachers and their ability to generate their own educational materials. The results of the pretest show that our students had an already high level of sustainability attitudes before implementing the teaching unit around ecofeminism. However, by using this approach, we have been able to observe a statistical significant increase in their environmental attitudes. In general, female students have higher sustainability consciousness in all studied dimensions, but no statistically significant differences were observed between genders, except for the society dimension in the posttest.

Although the binomial ecofeminism education has a long theoretical trajectory and many authors have stated its benefits, the implementation of concrete actions in educational settings is not fully developed. In this paper, we have shown that ecofeminism is a tool which can be used effectively to raise both environmental and gender awareness in pre-service teachers, who will transmit their views and values to their students in the 
near future. The outcome demonstrates that this teaching unit related to pedagogical ecofeminism has been able to generate attention and potentiate the creativity of the students while helping them assimilate the basic concepts and enrich their critical thinking, as observed in the qualitative analysis of the original short stories and proposed associated educational activities.

Educators have the responsibility to change those factors under their control, including issues related to sustainability and gender equality. We need to train teachers from a holistic point of view, with specific assignments designed to improve their creativity and their capacity to integrate different competencies around a topic. In doing so, they will be able to implement holistic education themselves and guide children in the good direction. Then, a needed change in future society will start to take place.

\section{References}

Abu-Alruz, J., Hailat, S., Al-Jaradat, M., \& Khasawneh, S. (2018). Attitudes toward pillars of sustainable development: The case for university Science education students in Jordan. Journal of Teacher Education for Sustainability, 20(2), 64-73. doi: 10.2478/jtes-2018-0015

AkÇa, F. (2019). Sustainable development in teacher education in terms of being solution oriented and self-efficacy. Sustainability, 11(23), 6878. doi: 10.3390/su11236878

Albareda-Tiana, S., Vidal-Raméntol, S., Pujol-Valls, M., \& Fernández-Morilla, M. (2018). Holistic approaches to develop sustainability and research competencies in pre-service teacher training. Sustainability, 10, 3698. doi: 10.3390/su10103698

Alghamdi, A., Ernest, J., \& Hafiz, F. (2017). Teaching sustainable practices as part of a holistic education in the Saudi context. International Journal of the Whole Child, 2(2), 29-40.

Andersson, K., Hussénius, A., \& Gustafsson, C. (2009). Gender theory as a tool for analysing science teaching. Teaching and Teacher Education, 25(2), 336-343. doi: 10.1016/j.tate.2008.09.011

Badjanova, J. (2013). Primary school teachers' views on a holistic approach to facilitating the acquisition of musical cultural values. Journal of Teacher Education for Sustainability, 15(2), 78-90. doi: 10.2478/jtes-2013-0013

Badjanova, J., Iliško, D., \& Drelinga, E. (2014). Holistic approach in reorienting teacher education towards the aim of sustainable education: The case study from the regional university in Latvia. Procedia - Social and Behavioral Sciences, 116, 2931-2935. doi: 10.1016/j.sbspro.2014.01.682

Berglund, T., Gericke, N., Boeve-de Pauw, J., Olsson, D., \& Chang, T.-C. (2020). A cross-cultural comparative study of sustainability consciousness between students in Taiwan and Sweden. Environment, Development and Sustainability, 22, 62876313. doi: 10.1007/s10668-019-00478-2

Bergman, B. G. (2016). Assessing impacts of locally designed environmental education projects on students' environmental attitudes, awareness, and intention to act. Environmental Education Research, 22, 480-503. doi: 10.1080/13504622.2014. 999225

Biasutti, M., \& Frate, S. (2017). A validity and reliability study of the Attitudes toward Sustainable Development scale. Environmental Education Research, 23(2), 214230. doi: 10.1080/13504622.2016.1146660 
Blanchet-Cohen, N., \& Reilly, R. C. (2013). Teachers' perspectives on environmental education in multicultural contexts: Towards culturally-responsive environmental education. Teaching and Teacher Education, 36(1), 13-22. doi: 10.1016/j.tate.2013. 07.001

Bloodhart, B., \& Swim, J. K. (2020). Sustainability and consumption: What's gender got to do with it? Journal of Social Issues, 76(1), 101-113. doi: 10.1111/josi.12370

Blumenfeld, P. C., Soloway, E., Marx, R. W., Rajcik, J. S., Guzdial, M., \& Palincsar, A. (1991). Motivating project-based learning: Sustaining the doing, supporting the learning. Educational Psychologist, 26(3-4), 369-398.

Chevallard, Y., \& Bosch, M. (2014). Didactic transposition in Mathematics education. In S. Lerman (Ed.), Encyclopedia of mathematics education (pp. 170-174). Springer.

Clover, D. E. (1995). Gender transformative learning and environmental action. Gender and Education, 7(3), 243-258. doi: 10.1080/09540259550038988

Echegoyen-Sanz, Y. (2019). Sostenibilidad y género. El ecofeminismo y su dimensión educativa [Gender and sustainability. Ecofeminism and its educational dimension]. In H. Rausell Guillot \& M. Talavera Ortega (Coords.), Género y didácticas. Una mirada crítica, una aproximación práctica [Gender and didactics. A critical view, a practical approach] (pp. 225-246). Tirant lo Blanch.

Echegoyen-Sanz, Y., \& Martín-Ezpeleta, A. (2018). Environmental humanities in preservice teachers' education. Journal of Education, Culture and Society, 9(2), 52-64. doi: 10.15503/jecs20182.52.64

Echegoyen-Sanz, Y., \& Martín-Ezpeleta, A. (2021). Creativity and ecofeminism in teacher training. Qualitative analysis of digital stories. Profesorado. Revista de currículum y formación del profesorado, 25(1), 23-44. doi: 10.30827/profesorado.v25i1.15290

Erden, F. T. (2009). A course on gender equity in education: Does it affect gender role attitudes of preservice teachers? Teaching and Teacher Education, 25(3), 409414. doi: 10.1016/j.tate.2008.11.001

Evans, N., Stevenson, R. B., Lasen, M., Ferreira, J.-A., \& Davis, J. (2017). Approaches to embedding sustainability in teacher education: A synthesis of the literature. Teaching and Teacher Education, 63, 405-417. doi: 10.1016/j.tate.2017.01.013

Fremerey, C., \& Bogner, F. X. (2015). Cognitive learning in authentic environments in relation to green attitude preferences. Studies in Educational Evaluation, 44, 9-15. doi: 10.1016/j.stueduc.2014.11.002

Gang, P. (1993). Holistic education. In C. L. Flake (Ed.), Holistic education: Principles, perspectives, and practices (pp. 86-91). Holistic Education Press.

Gough, A. (1999). Recognising women in environmental education pedagogy and research: Toward an ecofeminist poststructuralist perspective. Environmental Education Research, 5(2), 143-161. doi: 10.1080/1350462990050202

Gough, A., \& Whitehouse, H. (2019). Centering gender on the agenda for environmental education research. The Journal of Environmental Education, 50(4-6), 332-347. doi: 10.1080/00958964.2019.1703622

Grieshaber, S., \& McArdle, F. (2014). Ethical dimensions and perspectives on play. In L. Brooker, M. Balise, \& S. Edwards (Eds.), Sage handbook of play and learning in early childhood (pp. 103-114). Sage Publications.

Harvester, L., \& Blenkinshop, S. (2010). Environmental education and ecofeminist pedagogy: Bridging the environmental and the social. Canadian Journal of Environmental Education, 15, 120-134. 
Heise, U. K., Christensen, J., \& Niemann, M. (2017). The Routledge companion to the environmental humanities. Routledge.

Henderson, K. A. (1997). Ecofeminism and experiential education. The Journal of Experiential Education, 20(3), 130-133. doi: 0.1177/105382599702000304

Herman, C., \& Kirkup, G. (2017). Combining feminist pedagogy and transactional distance to create gender-sensitive technology-enhanced learning. Gender and Education, 29(6), 781-795. doi: 10.1080/09540253.2016.1187263

Herrero, Y. (2016). Una mirada para cambiar la película. Ecología, ecofeminismo y sostenibilidad [A look to change the movie. Ecology, ecofeminism and sustainability]. Ediciones Dyskolo.

Iorio, J. M., Hamm, C., Parnell, W., \& Quintero, E. (2017). Place, matters of concern, and pedagogy: Making impactful connections with our planet. Journal of Early Childhood Teacher Education, 38(2), 121-135. doi: 10.1080/10901027.2017.1306600

Larson, L. R., Castleberry, S. B., \& Green, G. T. (2010). Effects of an environmental education program on the environmental orientations of children from different gender, age, and ethnic groups. Journal of Park and Recreation Administration, 28, 95-113. doi: 10.1177/0013916509345212

Lawler, S. (2008). Stories and the social world. In M. Pickering (Ed.), Research methods for cultural studies (pp. 32-49). Edinburgh University Press.

Lemkow, A. F. (1990). The wholeness principle: Dynamics of unity within science, religion and society. Theosophical Publishing House.

Levine, D. S., \& Strube, M. J. (2012). Environmental attitudes, knowledge, intentions and behaviors among college students. The Journal of Social Psychology, 152, 308-326. doi: 10.1080/00224545.2011.604363

Li, H. (2007). Ecofeminism as a pedagogical project: Women, nature and education. Educational Theory, 57(3), 351-368. doi: 10.1111/j.1741-5446.2007.00262.x

Lieflander, A. K., y Bogner, F. X. (2014). The effects of children's age and sex on acquiring pro-environmental attitudes through environmental education. The Journal of Environmental Education, 45, 105-117. doi: 10.1080/00958964.2013.875511

Lijmbach, S., van Arcken, M. M., van Koppen, C. S. A., Wals, E. J. (2002). "Your view of nature is not mine!": Learning about pluralism in the classroom. Environmental Education Research, 8, 121-135. doi: 10.1080/13504620220128202

Martín-Ezpeleta, A., \& Echegoyen-Sanz, Y. (2020). Environmental attitudes in the literature classroom with preservice teachers. Profesorado: Revista de Currículum y Formación del Profesorado, 24(1), 184-202. doi: 10.30827/profesorado.v22i2.7725

Mónus, F. (2019). Comparing environmental awareness of Hungarian students in highschools with different socio-economical background. Journal of Applied Technical and Educational Sciences, 9(1), 1. doi: 10.24368/jates.v9i1.68

Nava, R. G. (2001). Holistic education: Pedagogy of universal love. Foundation for Educational Renewal.

Nagar, R. (2013). Storytelling and co-authorship in feminist alliance work: Reflections from a journey. Gender, Place and Culture, 20 (1), 1-18. doi: 10.1080/0966369X. 2012.731383

Olsson, D., Gericke, N., \& Chang Rundgren, S.-N. (2015). The effect of implementation of Education for Sustainable Development in Swedish compulsory schools - assessing pupils' sustainability consciousness. Environmental Education Research, 22(2), 176202. doi: 10.1080/13504622.2015.1005057 
Powell, R. B., Stern, M. J., Krohn, B. D., \& Ardoin, N. (2011). Development and validation of scales to measure environmental responsibility, character development, and attitudes toward school. Environmental Education Research, 17 (1), 91-111. doi: 10.1080/13504621003692891

Raftery, D., \& Valiulis, M. (2008). Gender balance/Gender bias: Issues in education research. Gender and Education, 20(4), 303-307. doi: 10.1080/09540250802190131

Robles, L. (2017). Yabarí. Cerbero.

Russell, C. L., \& Bell, A. C. (1996). A politized ethic of care: Environmental Education from an ecofeminist perspective. In K. Warren (Ed.), Women's voices in experiential education (pp. 172-181). Kendall Hunt.

Sakellari, M., \& Skanavis, C. (2013). Environmental behaviour and gender: An emerging area of concern for Environmental Education research. Applied Environmental Education \& Communication, 12, 77-87. doi: 10.1080/1533015X.2013.820633

Salite, I. (2015). Searching for sustainability in teacher education and educational research: Experiences from the Baltic and Black Sea Circle Consortium for educational research. Discourse and Communication for Sustainable Education, 6, 21-29. doi: 10.1515/ dcse-2015-0002

Salite, I., Fjodorova, I., Meihami, H., Ivanova, O., Iliško, Dz., \& Gholami, J. (2019). JTES approaches to sustainability: Current practices and new perspectives for a more sustainable world. Journal of Teacher Education for Sustainability, 21(2), 1-4. doi: 10.2478/jtes-2019-0012

Schneller, A. J., Johnson, B., \& Bogner, F. X. (2015). Measuring children's environmental attitudes and values in Northwest Mexico: Validating a modified version of measures to test the model of ecological values (2-MEV). Environmental Education Research, 21(1), 61-75. doi: 10.1080/13504622.2013.843648

Shephard, K. (2008). Higher education for sustainability: Seeking affective learning outcomes. International Journal of Sustainability in Higher Education, 9(1), 8798. doi: 10.1108/14676370810842201

Spencer, M. E., \& Nichols, S. E. (2010). Exploring Environmental Education through ecofeminism: Narratives of embodiment of science. In A. Bodzin, B. Shiner Klein, \& S. Weave (Eds.), The inclusion of Environmental Education in Science teacher education (pp. 255-266). Springer.

Staples, H. (2005). The integration of biomimicry as a solution-oriented approach to the Environmental Science curriculum for high school students. http://www.eric. ed.gov/ERICDocs/data/ericdocs2sql/content_storage_01/0000019b/80/1b/ c2/3d.pdf

Storey, J. (2012). Cultural theory and popular culture: An introduction, $6^{\text {th }}$ ed. Routledge. Sutton, S. G., \& Gyuris, E. (2015). Optimizing the environmental attitudes inventory. Establishing a baseline of change in students' attitudes. International Journal of Sustainability in Higher Education, 16, 16-33. doi: 10.1108/IJSHE-03-2013-0027

UNDP (2015). Sustainable Development Goals. https://www.undp.org/content/dam/ undp/library/corporate/brochure/SDGs_Booklet_Web_En.pdf

UNESCO. (2006). Framework for the UNDESD international implementation scheme. UNESCO.

UNESCO. (2014). Roadmap for implementing the global action programme on education for sustainable development. UNESCO. 
Wen-Hui, A. T. (2013). Constructing and practicing feminist pedagogy in Taiwan using a field study of the Twenty-Five Ladies Tomb. Gender, Place and Culture, 20(6), 811-826. doi: 10.1080/0966369X.2012.731382

Zell, S. K. (1998). Ecofeminism and the Science classroom: A practical approach. Science Education, 7(2), 143-158. doi: 10.1023/A:1008654323091

Correspondence concerning this article should be addressed to Yolanda EchegoyenSanz, Assistant Professor at the Department of Experimental and Social Sciences Teaching, University of Valencia, Av. dels Tarongers, 4, 46022 Valencia, Spain. Email: yolanda.echegoyen@uv.es 